medRxiv preprint doi: https://doi.org/10.1101/2020.04.09.20059626; this version posted April 14, 2020. The copyright holder for this preprint (which was not certified by peer review) is the author/funder, who has granted medRxiv a license to display the preprint in perpetuity.

\title{
Neutrophil extracellular traps (NETs) as markers of disease severity in COVID-19
}

Yu Zuo ${ }^{1}$, Srilakshmi Yalavarthi ${ }^{1}$, Hui Shi ${ }^{1,2}$, Kelsey Gockman ${ }^{1}$, Melanie Zuo ${ }^{3}$, Jacqueline A. Madison ${ }^{1}$, Christopher Blair ${ }^{4}$, Andrew Weber ${ }^{5}$, Betsy J. Barnes ${ }^{6,7}$, Mikala Egeblad ${ }^{8}$, Robert J. Woods $^{3}$, Yogendra Kanthi ${ }^{9,10 \ddagger}$, and Jason S. Knight ${ }^{1 \ddagger}$

‡ Yogendra Kanthi and Jason S. Knight are co-corresponding authors

\section{Affiliations}

${ }^{1}$ Division of Rheumatology, Department of Internal Medicine, University of Michigan, Ann Arbor, Michigan, USA

2 Division of Rheumatology, Ruijin Hospital, Shanghai Jiao Tong University School of Medicine, Shanghai, China

${ }^{3}$ Division of Geriatric and Palliative Medicine, Department of Internal Medicine, University of Michigan, Ann Arbor, Michigan, USA

${ }^{4}$ Division of Infectious Disease, Department of Internal Medicine, University of Michigan, Ann Arbor, Michigan, USA

${ }^{5}$ Division of Pulmonary, Critical Care, and Sleep Medicine, Department of Medicine, Northwell Health, New York, USA

${ }^{6}$ Center for Autoimmune, Musculoskeletal and Hematopoietic Diseases, The Feinstein Institutes for Medical Research, Manhasset, New York, USA

7 Departments of Molecular Medicine and Pediatrics, Zucker School of Medicine at Hofstra/Northwell, Hempstead, New York, USA

${ }^{8}$ Cold Spring Harbor Laboratory, Cold Spring Harbor, New York, USA

${ }^{9}$ Division of Cardiovascular Medicine, Department of Internal Medicine, University of Michigan, Ann Arbor, Michigan, USA

${ }^{10}$ Division of Cardiology, Ann Arbor Veterans Administration Healthcare System, Ann Arbor, Michigan, USA

Correspondence: Yogendra Kanthi, MD Jason S. Knight, MD, PhD ykanthi@umich.edu_isknight@umich.edu

Competing interests: Mikala Egeblad is receiving lonodelestat from Santhera for preclinical studies, but has no financial relationship with Santhera. 
medRxiv preprint doi: https://doi.org/10.1101/2020.04.09.20059626; this version posted April 14, 2020. The copyright holder for this preprint (which was not certified by peer review) is the author/funder, who has granted medRxiv a license to display the preprint in perpetuity.

All rights reserved. No reuse allowed without permission.

\begin{abstract}
In severe cases of coronavirus disease 2019 (COVID-19), viral pneumonia progresses to respiratory failure. Neutrophil extracellular traps (NETs) are extracellular webs of chromatin, microbicidal proteins, and oxidant enzymes that are released by neutrophils to contain infections. However, when not properly regulated, NETs have potential to propagate inflammation and microvascular thrombosis-including in the lungs of patients with acute respiratory distress syndrome. While elevated levels of blood neutrophils predict worse outcomes in COVID-19, the role of NETs has not been investigated. We now report that sera from patients with COVID-19 ( $n=50$ patients, $n=84$ samples) have elevated levels of cell-free DNA, myeloperoxidase(MPO)-DNA, and citrullinated histone $\mathrm{H3}$ (Cit-H3); the latter two are highly specific markers of NETs. Highlighting the potential clinical relevance of these findings, cell-free DNA strongly correlated with acute phase reactants including C-reactive protein, Ddimer, and lactate dehydrogenase, as well as absolute neutrophil count. MPO-DNA associated with both cell-free DNA and absolute neutrophil count, while Cit-H3 correlated with platelet levels. Importantly, both cell-free DNA and MPO-DNA were higher in hospitalized patients receiving mechanical ventilation as compared with hospitalized patients breathing room air. Finally, sera from individuals with COVID-19 triggered NET release from control neutrophils in vitro. In summary, these data reveal high levels of NETs in many patients with COVID-19, where they may contribute to cytokine release and respiratory failure. Future studies should investigate the predictive power of circulating NETs in longitudinal cohorts, and determine the extent to which NETs may be novel therapeutic targets in severe COVID-19.
\end{abstract}


medRxiv preprint doi: https://doi.org/10.1101/2020.04.09.20059626; this version posted April 14, 2020. The copyright holder for this preprint (which was not certified by peer review) is the author/funder, who has granted medRxiv a license to display the preprint in perpetuity.

All rights reserved. No reuse allowed without permission.

\section{INTRODUCTION}

To date, the coronavirus disease 2019 (COVID-19) pandemic has affected more than one million individuals from over 250 countries, and has resulted in unprecedented health, social, and economic crises (https://coronavirus.jhu.edu/map.html). The disease is caused by severe acute respiratory syndrome coronavirus 2 (SARS-CoV-2), manifesting with flu-like symptoms and a viral pneumonia that progresses to acute respiratory distress syndrome (ARDS) and even multi-organ failure in some individuals (1).

Elevated levels of blood neutrophils are an early indicator of SARS-CoV-2 infection, predicting severe respiratory disease and worse outcomes $(2,3)$. Over the past decade, our group and many others have revealed a pathogenic role for neutrophil-derived neutrophil extracellular traps (NETs) in various thrombo-inflammatory states including sepsis $(4,5)$, thrombosis $(6-8)$, and respiratory failure $(9,10)$. NETs are extracellular webs of DNA, histones, microbicidal proteins, and oxidant enzymes that are released by neutrophils to corral infections; however, when not properly regulated, NETs have potential to initiate and propagate inflammation and thrombosis $(11,12)$. Indeed, inhibition of neutrophils and NETs are protective in various models of influenza-associated ARDS (13-16). Although it has yet to be assessed whether NETs contribute to the inflammatory storm that leads to respiratory failure in many COVID-19 patients, there is emerging evidence to implicate inflammatory cytokines such as interleukin (IL)-1 $\beta$ and IL-6 in the COVID-19 milieu (17). Not surprisingly, NETs are intimately intertwined with both cytokines, and especially IL-1 $\beta$, in many pulmonary and cardiovascular diseases $(8,18-23)$.

While the definitive accounting of COVID-19 pathophysiology will likely await the development of model systems, it is clear that other pandemic viruses including influenza H1N1, SARS-CoV, and MERS-CoV are associated with neutrophilic infiltration at sites of infection and development of ARDS $(24,25)$. The acute, exudative phase of ARDS is characterized by an exuberant immune response productive of pro-inflammatory cytokines and chemokines; increased neutrophil infiltration and accumulation in the alveoli; and disruption of the alveolar epithelialcapillary barrier (26). Culturing neutrophils in vitro with influenza-infected lung epithelial cells triggers NETosis and augments endothelial damage by culture supernatants (13). Neutrophildepleted mice demonstrate milder lung pathology in response to influenza infection, including lower levels of thrombomodulin, matrix metalloproteinases, and myeloperoxidase (MPO) in bronchoalveolar lavage fluid (13). At the same time, influenza-infected mice are protected by 
medRxiv preprint doi: https://doi.org/10.1101/2020.04.09.20059626; this version posted April 14, 2020. The copyright holder for this preprint (which was not certified by peer review) is the author/funder, who has granted medRxiv a license to display the preprint in perpetuity.

All rights reserved. No reuse allowed without permission.

strategies that prevent NETosis including inhibition of superoxide dismutase (13) and MPO (13, 27). In patients with influenza A infection, high levels of NETs predict a poor prognosis (28).

Work to date exploring pathophysiology of COVID-19 has focused especially on macrophages and epithelial cells, with little attention paid to neutrophils and their catalysts, checkpoints, and effector mechanisms-all of which could add actionable context to our understanding of the COVID-19 inflammatory storm. Here, as a first step toward assessing the role of NETs in COVID-19, we sought to measure various markers of NETs in sera of hospitalized patients and to determine their relationship to severity of illness. 
medRxiv preprint doi: https://doi.org/10.1101/2020.04.09.20059626; this version posted April 14, 2020. The copyright holder for this preprint (which was not certified by peer review) is the author/funder, who has granted medRxiv a license to display the preprint in perpetuity.

All rights reserved. No reuse allowed without permission.

\section{RESULTS}

Detection of NETs in sera of COVID-19 patients. Serum samples were obtained from 50 patients hospitalized with COVID-19 at a large academic hospital (Table 1). As compared with serum samples from 30 healthy controls, the COVID-19 samples showed higher levels of cellfree DNA (Figure 1A), myeloperoxidase-DNA complexes (MPO-DNA, Figure 1B), and citrullinated histone H3 (Cit-H3, Figure 1C). The latter two markers are generally regarded as highly specific for NET remnants. While cell-free DNA and MPO-DNA demonstrated a significant correlative relationship (Figure 1D), the association between cell-free DNA and CitH3 was not significant (Figure 1E). For a subset of the patients $(n=22)$, longitudinal serum samples were available. For most, levels of NET markers were relatively stable over several days (Supplementary Figure 1). All available samples $(n=84)$ were included in the subsequent correlation analyses. In summary, three markers indicative of NET remnants are elevated in sera of COVID-19 patients as compared with controls.

Association between NETs and clinical biomarkers. Given that circulating NETs may be drivers of, or form in response to, other blood products, we next asked how the aforementioned NET markers compared to several commonly available clinical tests. Specifically, we assessed potential correlations with C-reactive protein, D-dimer, lactate dehydrogenase, absolute neutrophil count, and platelet count. To draw integral comparisons, we limited the analysis of clinical laboratory measurements to those performed on the same day as serum used for NET assays. Cell-free DNA demonstrated a strong positive correlation with all of the clinical tests other than platelet count (Figure 2A-D). When we compared the clinical labs with MPO-DNA, we detected a strong positive correlation with absolute neutrophil count (Figure 2E), while Creactive protein $(r=0.10, p=0.44)$, $D$-dimer $(r=0.05, p=0.72)$ and lactate dehydrogenase $(r=0.17$, $\mathrm{p}=0.22$ ) demonstrated positive slopes that were not statistically significant. Interestingly, Cit-H3 levels were positively correlated with platelet counts (Figure 2F), but not the other clinical laboratory measurements. In summary, cell-free DNA and to a lesser extent MPO-DNA and Cit$\mathrm{H} 3$ demonstrate significant correlations with clinical studies routinely used in the care of COVID19 patients.

NETs associate with severe disease including mechanical ventilation. We next determined the clinical status associated with each available serum sample. We compared samples from patients with severe COVID-19 (those requiring mechanical ventilation, $n=27$ samples) to patients with mild or moderate COVID-19 (oxygen saturation >94\% on ambient air, 
medRxiv preprint doi: https://doi.org/10.1101/2020.04.09.20059626; this version posted April 14, 2020. The copyright holder for this preprint (which was not certified by peer review) is the author/funder, who has granted medRxiv a license to display the preprint in perpetuity.

All rights reserved. No reuse allowed without permission.

$\mathrm{n}=24$ samples). As compared with patients breathing room air, patients requiring mechanical ventilation had significantly higher levels of cell-free DNA (Figure 3A) and MPO-DNA (Figure 3B), but not Cit-H3 (Figure 3C). Absolute neutrophil counts were not significantly higher in the ventilated patients (Figure 3D). In summary, these data suggest a possible relationship between level of serum NETs and severity of COVID-19.

COVID-19 sera trigger control neutrophils to release NETs. If COVID-19 presents a milieu favoring NETosis, we reasoned that direct exposure of control neutrophils to patient sera (without any additional agonist) would trigger these healthy neutrophils to undergo NETosis. As compared with heterologous control sera, the patient sera robustly promoted NETosis whether measured by externalization of DNA (Figure 4A) or release of DNA-bound MPO enzyme (Figure 4B). Immunofluorescence microscopy demonstrated extracellular chromatin structures decorated with neutrophil elastase characteristic of NETs (Figure 4C). In summary, serum samples from COVID-19 patients robustly trigger healthy neutrophils to undergo NETosis. 
medRxiv preprint doi: https://doi.org/10.1101/2020.04.09.20059626; this version posted April 14, 2020. The copyright holder for this preprint (which was not certified by peer review) is the author/funder, who has granted medRxiv a license to display the preprint in perpetuity.

All rights reserved. No reuse allowed without permission.

\section{DISCUSSION}

Here, we report for the first time elevated levels of serum NETs in many hospitalized patients with COVID-19. We measured three markers commonly used to detect NET remnants in blood (cell-free DNA, Cit-H3, and MPO-DNA), and found significant elevations in all three. We also found that COVID-19 sera are potent stimulators of NETosis when added to control neutrophils. Together, these data provide evidence that COVID-19, at least in hospitalized patients, is a proNETotic state. The triggers of NETosis in COVID-19 are potentially myriad and will require further investigation. Possibilities include virus-damaged epithelial cells $(13,29)$, activated platelets $(30,31)$, activated endothelial cells (32), and inflammatory cytokines such as IL-1 $(19$, 33), IL-8 (34, 35), granulocyte colony stimulating factor $(36,37)$, and likely others (17).

Of the markers we tested, cell-free DNA was most closely associated with traditional inflammatory markers used to track COVID-19 including C-reactive protein, D-dimer, and lactate dehydrogenase. Notably, although cell-free DNA is not a highly specific marker for NETs, it was strongly correlated with absolute neutrophil count, as was the more specific marker of NETs, MPO-DNA. Somewhat unexpectedly, Cit-H3 did not correlate well with the other two markers, but did associate strongly with platelet levels. It is believed that the predominant driver of histone citrullination (i.e., production of $\mathrm{Cit}-\mathrm{H} 3$ ) in NETs is the enzyme peptidlyarginine deiminase 4 (PAD4) (38). However, neutrophils can be triggered to undergo NETosis by a variety of stimuli, and in vitro studies demonstrate that not all pathways to NETosis are equally reliant on PAD4 activity (39); for example, stimuli that lead to robust reactive oxygen species production may be relatively PAD4-independent (40). The dichotomy between MPO-DNA and Cit-H3 levels in the COVID-19 sera tested here potentially suggests that two or more pathways to NETosis are active in COVID-19 patients, with the pathway leading to Cit-H3 perhaps having some relationship to platelets (41).

NETs were first described in 2004 as a novel pathogen eradication strategy that could function as an alternative to phagocytosis (35), but it is now recognized that NETs have double-edgedsword properties and likely exacerbate (and in some cases even initiate) autoimmune and vascular diseases (42). NETs present and stabilize a variety of oxidant enzymes in the extracellular space, including MPO, NADPH oxidase, and nitric oxide synthase (43), while also serving as a source of extracellular histones that carry significant cytotoxic potential $(44,45)$. In light of these toxic cargo, it is not surprising that NETs play a role in a variety of lung diseases including cystic fibrosis (where they occlude larger airways) (46), smoking-related lung disease 
medRxiv preprint doi: https://doi.org/10.1101/2020.04.09.20059626; this version posted April 14, 2020. The copyright holder for this preprint (which was not certified by peer review) is the author/funder, who has granted medRxiv a license to display the preprint in perpetuity.

All rights reserved. No reuse allowed without permission.

(47), and, with particular relevance here, pathogen-induced acute lung injury and ARDS (13, 48, 49). NETs have also been very well studied in the setting of cardiovascular disease where they infiltrate and propagate inflammation in the vessel wall (50), and, when formed intravascularly, occlude arteries (51), veins (52), and microscopic vessels (53). Early studies of COVID-19 suggest a high risk of morbid arterial events (54), and one can speculate that the risk of venous thrombosis will increasingly reveal itself as more data become available (55).

Severe COVID-19 appears to be defined by neutrophilia, as well as elevations in IL-1 $\beta$, IL-6, and D-dimer (17), the latter suggesting hyperactivity of the coagulation system. All these findings have significant potential for cross-talk with NETs. NETs are linked to IL-1ß (both upstream and downstream) in cardiovascular and pulmonary diseases (18-21), including as described by our group for venous thrombosis (8). The same is true for IL-6, either directly (22), or perhaps with IL-1 $\beta$ as an intermediary (23). Of course, as discussed above, examples of NETs as drivers of thrombosis are myriad, as intravascular NETosis is responsible for initiation and accretion of thrombotic events in arteries, veins, and-particularly pertinent to COVID-19the microvasculature, where thrombotic disease can drive end-organ damage in lungs, heart, kidneys, and other organs $(56,57)$. Mechanistically, NETs, via electrostatic interactions, activate the contact pathway of coagulation (58), while also presenting tissue factor to activate the intrinsic pathway (59). Simultaneously, serine proteases in NETs dismantle natural brakes on coagulation such as tissue factor pathway inhibitor and antithrombin (60). Bidirectional interplay between NETs and platelets may also be critical for COVID-19-associated microvascular thrombosis as has been characterized in a variety of disease models $(57,58)$.

Of interest, a recent small study performed in China suggested potential efficacy of the adenosine-receptor agonist, dipyridamole in severe cases of COVID-19 (61). Dipyridamole is an FDA-approved drug that our group recently discovered to inhibit NET formation by activation of adenosine $A_{2 A}$ receptors (6). In the aforementioned trial, patients with COVID-19-associated bilateral pneumonia were treated with oral dipyridamole for seven days, in additional to treatment with antiviral agents (61). As compared with controls, dipyridamole-treated patients demonstrated improvements in platelet counts and D-dimer levels (61). Given the urgent need for effective treatments of COVID-19, a randomized study to characterize the impact of dipyridamole on COVID-19-related NETosis, thrombo-inflammatory storm, and, of course, outcomes may be warranted. 
medRxiv preprint doi: https://doi.org/10.1101/2020.04.09.20059626; this version posted April 14, 2020. The copyright holder for this preprint (which was not certified by peer review) is the author/funder, who has granted medRxiv a license to display the preprint in perpetuity.

All rights reserved. No reuse allowed without permission.

Other approaches to combatting NETs have been reviewed $(62,63)$, and include the dismantling of already-formed NETs (deoxyribonucleases) and strategies that might prevent initiation of NET release, including inhibitors of neutrophil elastase and PAD4. While our study certainly has limitations including the use of serum (plasma is typically preferred by our group and others for measurement of NETs) and a relatively small sample size, we hope it will ignite further research into the role of neutrophil effector functions in the complications of COVID-19. As a first step, future studies should investigate the predictive power of circulating NETs in wellphenotyped longitudinal cohorts. Furthermore, given the dichotomy we found here between MPO-DNA and Cit-H3, investigators should be encouraged to continue to include diverse markers of NETosis in future studies. As we await definitive antiviral and immunologic solutions to the current pandemic, we posit that anti-neutrophil therapies may be part of a personalized strategy for some individuals affected by COVID-19 who are at risk for progression to respiratory failure. 
medRxiv preprint doi: https://doi.org/10.1101/2020.04.09.20059626; this version posted April 14, 2020. The copyright holder for this preprint (which was not certified by peer review) is the author/funder, who has granted medRxiv a license to display the preprint in perpetuity.

All rights reserved. No reuse allowed without permission.

\section{METHODS}

Human samples. Serum samples from 50 hospitalized COVID-19 patients (84 total samples) were used in this study. Blood was collected into serum separator tubes containing clot activator and serum separator gel by a trained hospital phlebotomist. After completion of biochemical testing ordered by the clinician, the remaining serum was stored at $4^{\circ} \mathrm{C}$ for up to 48 hours before it was deemed "discarded" and released to the research laboratory. Serum samples were immediately divided into small aliquots and stored at $-80^{\circ} \mathrm{C}$ until the time of testing. All 50 patients had a confirmed COVID-19 diagnosis based on FDA-approved RNA testing. This study complied with all relevant ethical regulations, and was approved by the University of Michigan Institutional Review Board (HUM00179409), which waived the requirement for informed consent given the discarded nature of the samples. Healthy volunteers were recruited through a posted flyer; exclusion criteria for these controls included history of a systemic autoimmune disease, active infection, and pregnancy. For preparation of control serum, blood was collected into serum separator tubes containing clot activator and serum separator gel by a trained hospital phlebotomist. These serum samples were divided into small aliquots and stored at $-80^{\circ} \mathrm{C}$ until the time of testing.

Quantification of cell-free DNA. Cell-free DNA was quantified in sera using the Quant-iT PicoGreen dsDNA Assay Kit (Invitrogen, P11496) according to the manufacturer's instructions.

Quantification of citrullinated histone H3. Citrullinated histone H3 was quantified in sera using the Citrullinated Histone H3 (Clone 11D3) ELISA Kit (Cayman, 501620) according to the manufacturer's instructions.

Quantification of MPO-DNA complexes. MPO-DNA complexes were quantified similarly to what has been previously described (64). This protocol used several reagents from the Cell Death Detection ELISA kit (Roche). First, a high-binding EIA/RIA 96-well plate (Costar) was coated overnight at $4^{\circ} \mathrm{C}$ with anti-human MPO antibody (Bio-Rad 0400-0002), diluted to a concentration of $1 \mu \mathrm{g} / \mathrm{ml}$ in coating buffer (Cell Death kit). The plate was washed two times with wash buffer (0.05\% Tween 20 in PBS), and then blocked with $4 \%$ bovine serum albumin in PBS (supplemented with $0.05 \%$ Tween 20 ) for 2 hours at room temperature. The plate was again washed five times, before incubating for 90 minutes at room temperature with $10 \%$ serum or plasma in the aforementioned blocking buffer (without Tween 20). The plate was washed five times, and then incubated for 90 minutes at room temperature with 10x anti-DNA antibody 
medRxiv preprint doi: https://doi.org/10.1101/2020.04.09.20059626; this version posted April 14, 2020. The copyright holder for this preprint (which was not certified by peer review) is the author/funder, who has granted medRxiv a license to display the preprint in perpetuity.

All rights reserved. No reuse allowed without permission.

(HRP-conjugated; from the Cell Death kit) diluted 1:100 in blocking buffer. After five more washes, the plate was developed with 3,3',5,5'-Tetramethylbenzidine (TMB) substrate (Invitrogen) followed by a 2N sulfuric acid stop solution. Absorbance was measured at a wavelength of $450 \mathrm{~nm}$ using a Cytation 5 Cell Imaging Multi-Mode Reader (BioTek). Data were normalized to in vitro-prepared NET standards included on every plate, which were quantified based on their DNA content.

Human neutrophil purification. For neutrophil preparation, blood from healthy volunteers was collected into sodium citrate tubes by standard phlebotomy techniques. The anticoagulated blood was then fractionated by density-gradient centrifugation using Ficoll-Paque Plus (GE Healthcare). Neutrophils were further purified by dextran sedimentation of the red blood cell layer, before lysing residual red blood cells with $0.2 \%$ sodium chloride. Neutrophil preparations were at least $95 \%$ pure as confirmed by nuclear morphology.

NETosis assay (SYTOX Green). A cell-impermeant dye SYTOX Green (Thermo Fisher) was used to measure NETosis. Briefly, purified neutrophils were resuspended in 1x PBS (Gibco). $1 \times 10^{5}$ neutrophils were seeded into each well of a $0.001 \%$ poly-L-lysine (Sigma)-coated 96-well black clear-bottom non-tissue culture plate (Costar), and were allowed to adhere for 20 minutes at $37^{\circ} \mathrm{C}$ and $5 \% \mathrm{CO}_{2}$. PBS was gently removed and control/patient serum (diluted to $10 \%$ in RPMI culture media supplemented with L-glutamine) was carefully added without disrupting adherent cells. SYTOX Green was added at the same time to a final concentration of $500 \mathrm{nM}$. All treatments were done in triplicate. Cells were allowed to undergo NETosis for 4 hours. Culture media was then gently removed and fresh $1 \times$ PBS was added to each well.

Fluorescence was quantified at excitation and emission wavelengths of $504 \mathrm{~nm}$ and $523 \mathrm{~nm}$, respectively, using a Cytation 5 Cell Imaging Multi-Mode Reader (BioTek). Data were collected using the area-scan setting of the plate reader.

NETosis assay (NET-associated MPO). Purified neutrophils were resuspended in RPMI media (Gibco) supplemented with $0.5 \%$ bovine serum albumin (BSA, Sigma), 0.5\% heatinactivated fetal bovine serum (FBS, Gibco) and L-glutamine. Neutrophils ( $1 \times 10^{5} /$ well) were cultured in a 96-well tissue culture plate (Costar) in the presence of either patient or control serum, diluted to a final concentration of $10 \%$. Plates were incubated for 3 hours at $37^{\circ} \mathrm{C}$ and $5 \% \mathrm{CO}_{2}$. To collect NET-associated MPO, the culture media was discarded (to remove any soluble MPO) and replaced with $100 \mu \mathrm{L}$ of PBS supplemented with $5 \mathrm{U} / \mathrm{ml}$ Micrococcal nuclease 
medRxiv preprint doi: https://doi.org/10.1101/2020.04.09.20059626; this version posted April 14, 2020. The copyright holder for this preprint (which was not certified by peer review) is the author/funder, who has granted medRxiv a license to display the preprint in perpetuity.

All rights reserved. No reuse allowed without permission.

(Thermo Fisher). After 10 minutes at $37^{\circ} \mathrm{C}$, digestion of NETs was stopped with $10 \mathrm{mM}$ EDTA. Supernatants were transferred to a v-shaped 96 well plate, and centrifuged at 400xg for 5 minutes to remove debris. Supernatants were then transferred into a new flat-bottom 96-well plate. To quantify MPO activity, an equal volume of 3,3',5,5'-tetramethylbenzidine (TMB) substrate (Thermo Fisher) was added to each well. After 10 minutes of incubation in the dark, the reaction was stopped by the $2 \mathrm{~N}$ sulfuric acid solution. Absorbance was measured at 450 nm using a Cytation 5 Cell Imaging Multi-Mode Reader.

NETosis assay (microscopy). For immunofluorescence microscopy, $1 \times 10^{5}$ neutrophils were seeded onto coverslips coated with $0.001 \%$ poly-L-lysine (Sigma) and cultured as for the above assays. Samples were then fixed with $4 \%$ paraformaldehyde for 10 minutes at room temperature, followed by blocking with $10 \%$ FBS in PBS. The primary antibody was against neutrophil elastase (Abcam 21595, diluted 1:100), and the FITC-conjugated secondary antibody was from SouthernBiotech (4052-02, diluted 1:250). DNA was stained with Hoechst 33342 (Invitrogen). Images were collected with a Cytation 5 Cell Imaging Multi-Mode Reader.

Statistical analysis. Normally-distributed data were analyzed by two-sided t test and skewed data were analyzed by Mann-Whitney test. Data analysis was with GraphPad Prism software version 8. Correlations were tested by Pearson's correlation coefficient. Statistical significance was defined as $p<0.05$ unless stated otherwise. 
medRxiv preprint doi: https://doi.org/10.1101/2020.04.09.20059626; this version posted April 14, 2020. The copyright holder for this preprint (which was not certified by peer review) is the author/funder, who has granted medRxiv a license to display the preprint in perpetuity.

All rights reserved. No reuse allowed without permission.

\section{REFERENCES}

1. Pedersen SF, and Ho YC. SARS-CoV-2: A Storm is Raging. J Clin Invest. 2020.

2. $\quad$ Zhang B, Zhou X, Zhu C, Feng F, Qiu Y, Feng J, et al. Immune phenotyping based on neutrophil-to-lymphocyte ratio and IgG predicts disease severity and outcome for patients with COVID-19. 2020:2020.03.12.20035048.

3. Song C-Y, Xu J, He J-Q, and Lu Y-Q. COVID-19 early warning score: a multi-parameter screening tool to identify highly suspected patients. 2020:2020.03.05.20031906.

4. Iba T, Levy JH, Raj A, and Warkentin TE. Advance in the Management of SepsisInduced Coagulopathy and Disseminated Intravascular Coagulation. J Clin Med. 2019;8(5).

5. Ward PA, and Fattahi F. New strategies for treatment of infectious sepsis. J Leukoc Biol. 2019;106(1):187-92.

6. Ali RA, Gandhi AA, Meng H, Yalavarthi S, Vreede AP, Estes SK, et al. Adenosine receptor agonism protects against NETosis and thrombosis in antiphospholipid syndrome. Nat Commun. 2019;10(1):1916.

7. Meng H, Yalavarthi S, Kanthi Y, Mazza LF, Elfline MA, Luke CE, et al. In Vivo Role of Neutrophil Extracellular Traps in Antiphospholipid Antibody-Mediated Venous Thrombosis. Arthritis Rheumatol. 2017;69(3):655-67.

8. Yadav V, Chi L, Zhao R, Tourdot BE, Yalavarthi S, Jacobs BN, et al. Ectonucleotidase tri(di)phosphohydrolase-1 (ENTPD-1) disrupts inflammasome/interleukin 1beta-driven venous thrombosis. J Clin Invest. 2019;129(7):2872-7.

9. Potey PM, Rossi AG, Lucas CD, and Dorward DA. Neutrophils in the initiation and resolution of acute pulmonary inflammation: understanding biological function and therapeutic potential. J Pathol. 2019;247(5):672-85.

10. Frantzeskaki F, Armaganidis A, and Orfanos SE. Immunothrombosis in Acute Respiratory Distress Syndrome: Cross Talks between Inflammation and Coagulation. Respiration. 2017;93(3):212-25.

11. Twaddell SH, Baines KJ, Grainge C, and Gibson PG. The Emerging Role of Neutrophil Extracellular Traps in Respiratory Disease. Chest. 2019;156(4):774-82.

12. Porto BN, and Stein RT. Neutrophil Extracellular Traps in Pulmonary Diseases: Too Much of a Good Thing? Front Immunol. 2016;7:311.

13. Narasaraju T, Yang E, Samy RP, Ng HH, Poh WP, Liew AA, et al. Excessive neutrophils and neutrophil extracellular traps contribute to acute lung injury of influenza pneumonitis. Am J Pathol. 2011;179(1):199-210.

14. Moorthy AN, Tan KB, Wang S, Narasaraju T, and Chow VT. Effect of High-Fat Diet on the Formation of Pulmonary Neutrophil Extracellular Traps during Influenza Pneumonia in BALB/c Mice. Front Immunol. 2016;7:289.

15. Rudd JM, Pulavendran S, Ashar HK, Ritchey JW, Snider TA, Malayer JR, et al. Neutrophils Induce a Novel Chemokine Receptors Repertoire During Influenza Pneumonia. Front Cell Infect Microbiol. 2019;9:108.

16. Ashar HK, Mueller NC, Rudd JM, Snider TA, Achanta M, Prasanthi M, et al. The Role of Extracellular Histones in Influenza Virus Pathogenesis. Am J Pathol. 2018;188(1):13548.

17. Mehta P, McAuley DF, Brown M, Sanchez E, Tattersall RS, Manson JJ, et al. COVID-19: consider cytokine storm syndromes and immunosuppression. Lancet. 2020.

18. Liberale L, Holy EW, Akhmedov A, Bonetti NR, Nietlispach F, Matter CM, et al. Interleukin-1beta Mediates Arterial Thrombus Formation via NET-Associated Tissue Factor. J Clin Med. 2019;8(12). 
medRxiv preprint doi: https://doi.org/10.1101/2020.04.09.20059626; this version posted April 14, 2020. The copyright holder for this preprint (which was not certified by peer review) is the author/funder, who has granted medRxiv a license to display the preprint in perpetuity.

All rights reserved. No reuse allowed without permission.

19. Meher AK, Spinosa M, Davis JP, Pope N, Laubach VE, Su G, et al. Novel Role of IL (Interleukin)-1beta in Neutrophil Extracellular Trap Formation and Abdominal Aortic Aneurysms. Arterioscler Thromb Vasc Biol. 2018;38(4):843-53.

20. Josefs T, Barrett TJ, Brown EJ, Quezada A, Wu X, Voisin M, et al. Neutrophil Extracellular Traps (NETs) promote macrophage inflammation and impair atherosclerosis resolution in mice with diabetes. JCI Insight. 2020.

21. Lachowicz-Scroggins ME, Dunican EM, Charbit AR, Raymond W, Looney MR, Peters MC, et al. Extracellular DNA, Neutrophil Extracellular Traps, and Inflammasome Activation in Severe Asthma. Am J Respir Crit Care Med. 2019;199(9):1076-85.

22. Merza M, Hartman H, Rahman M, Hwaiz R, Zhang E, Renstrom E, et al. Neutrophil Extracellular Traps Induce Trypsin Activation, Inflammation, and Tissue Damage in Mice With Severe Acute Pancreatitis. Gastroenterology. 2015;149(7):1920-31 e8.

23. Ridker PM. From C-Reactive Protein to Interleukin-6 to Interleukin-1: Moving Upstream To Identify Novel Targets for Atheroprotection. Circ Res. 2016;118(1):145-56.

24. Perlman S, and Dandekar AA. Immunopathogenesis of coronavirus infections: implications for SARS. Nat Rev Immunol. 2005;5(12):917-27.

25. Blondonnet R, Constantin JM, Sapin V, and Jabaudon M. A Pathophysiologic Approach to Biomarkers in Acute Respiratory Distress Syndrome. Dis Markers. 2016;2016:3501373.

26. Matthay MA, Zemans RL, Zimmerman GA, Arabi YM, Beitler JR, Mercat A, et al. Acute respiratory distress syndrome. Nat Rev Dis Primers. 2019;5(1):18.

27. Sugamata R, Dobashi H, Nagao T, Yamamoto K, Nakajima N, Sato Y, et al. Contribution of neutrophil-derived myeloperoxidase in the early phase of fulminant acute respiratory distress syndrome induced by influenza virus infection. Microbiol Immunol. 2012;56(3):171-82.

28. Zhu L, Liu L, Zhang Y, Pu L, Liu J, Li X, et al. High Level of Neutrophil Extracellular Traps Correlates With Poor Prognosis of Severe Influenza A Infection. J Infect Dis. 2018;217(3):428-37.

29. Cortjens B, de Boer OJ, de Jong R, Antonis AF, Sabogal Pineros YS, Lutter R, et al. Neutrophil extracellular traps cause airway obstruction during respiratory syncytial virus disease. J Pathol. 2016;238(3):401-11.

30. Clark SR, Ma AC, Tavener SA, McDonald B, Goodarzi Z, Kelly MM, et al. Platelet TLR4 activates neutrophil extracellular traps to ensnare bacteria in septic blood. Nat Med. 2007;13(4):463-9.

31. McDonald B, Davis RP, Kim SJ, Tse M, Esmon CT, Kolaczkowska E, et al. Platelets and neutrophil extracellular traps collaborate to promote intravascular coagulation during sepsis in mice. Blood. 2017;129(10):1357-67.

32. Gupta AK, Joshi MB, Philippova M, Erne P, Hasler P, Hahn S, et al. Activated endothelial cells induce neutrophil extracellular traps and are susceptible to NETosismediated cell death. FEBS Lett. 2010;584(14):3193-7.

33. Sil P, Wicklum H, Surell C, and Rada B. Macrophage-derived IL-1beta enhances monosodium urate crystal-triggered NET formation. Inflamm Res. 2017;66(3):227-37.

34. Gupta AK, Hasler P, Holzgreve W, Gebhardt S, and Hahn S. Induction of neutrophil extracellular DNA lattices by placental microparticles and IL-8 and their presence in preeclampsia. Hum Immunol. 2005;66(11):1146-54.

35. Brinkmann V, Reichard U, Goosmann C, Fauler B, Uhlemann Y, Weiss DS, et al. Neutrophil extracellular traps kill bacteria. Science. 2004;303(5663):1532-5.

36. Demers M, Krause DS, Schatzberg D, Martinod K, Voorhees JR, Fuchs TA, et al. Cancers predispose neutrophils to release extracellular DNA traps that contribute to cancer-associated thrombosis. Proc Natl Acad Sci U S A. 2012;109(32):13076-81. 
medRxiv preprint doi: https://doi.org/10.1101/2020.04.09.20059626; this version posted April 14, 2020. The copyright holder for this preprint (which was not certified by peer review) is the author/funder, who has granted medRxiv a license to display the preprint in perpetuity.

All rights reserved. No reuse allowed without permission.

37. Cedervall J, Zhang Y, Huang H, Zhang L, Femel J, Dimberg A, et al. Neutrophil Extracellular Traps Accumulate in Peripheral Blood Vessels and Compromise Organ Function in Tumor-Bearing Animals. Cancer Res. 2015;75(13):2653-62.

38. Wong SL, and Wagner DD. Peptidylarginine deiminase 4: a nuclear button triggering neutrophil extracellular traps in inflammatory diseases and aging. FASEB J. 2018:fj201800691R.

39. Tatsiy O, and McDonald PP. Physiological Stimuli Induce PAD4-Dependent, ROSIndependent NETosis, With Early and Late Events Controlled by Discrete Signaling Pathways. Front Immunol. 2018;9:2036.

40. Kenny EF, Herzig A, Kruger R, Muth A, Mondal S, Thompson PR, et al. Diverse stimuli engage different neutrophil extracellular trap pathways. Elife. 2017;6.

41. Zucoloto AZ, and Jenne CN. Platelet-Neutrophil Interplay: Insights Into Neutrophil Extracellular Trap (NET)-Driven Coagulation in Infection. Front Cardiovasc Med. 2019;6:85.

42. Wigerblad G, and Kaplan MJ. NETs spread ever wider in rheumatic diseases. Nat Rev Rheumatol. 2020;16(2):73-4.

43. Smith CK, Vivekanandan-Giri A, Tang C, Knight JS, Mathew A, Padilla RL, et al. Neutrophil extracellular trap-derived enzymes oxidize high-density lipoprotein: an additional proatherogenic mechanism in systemic lupus erythematosus. Arthritis Rheumatol. 2014;66(9):2532-44.

44. Silvestre-Roig C, Braster Q, Wichapong K, Lee EY, Teulon JM, Berrebeh N, et al. Externalized histone $\mathrm{H} 4$ orchestrates chronic inflammation by inducing lytic cell death. Nature. 2019;569(7755):236-40.

45. Saffarzadeh M, Juenemann C, Queisser MA, Lochnit G, Barreto G, Galuska SP, et al. Neutrophil extracellular traps directly induce epithelial and endothelial cell death: a predominant role of histones. PLoS One. 2012;7(2):e32366.

46. Dwyer M, Shan Q, D'Ortona S, Maurer R, Mitchell R, Olesen H, et al. Cystic fibrosis sputum DNA has NETosis characteristics and neutrophil extracellular trap release is regulated by macrophage migration-inhibitory factor. J Innate Immun. 2014;6(6):765-79.

47. Dicker AJ, Crichton ML, Pumphrey EG, Cassidy AJ, Suarez-Cuartin G, Sibila O, et al. Neutrophil extracellular traps are associated with disease severity and microbiota diversity in patients with chronic obstructive pulmonary disease. J Allergy Clin Immunol. 2018;141(1):117-27.

48. Lefrancais E, Mallavia B, Zhuo H, Calfee CS, and Looney MR. Maladaptive role of neutrophil extracellular traps in pathogen-induced lung injury. JCI Insight. 2018;3(3).

49. Liu S, Su X, Pan P, Zhang L, Hu Y, Tan H, et al. Neutrophil extracellular traps are indirectly triggered by lipopolysaccharide and contribute to acute lung injury. Sci Rep. 2016;6:37252.

50. Warnatsch A, loannou M, Wang Q, and Papayannopoulos V. Inflammation. Neutrophil extracellular traps license macrophages for cytokine production in atherosclerosis. Science. 2015;349(6245):316-20.

51. Doring Y, Soehnlein O, and Weber C. Neutrophil Extracellular Traps in Atherosclerosis and Atherothrombosis. Circ Res. 2017;120(4):736-43.

52. Brill A, Fuchs TA, Savchenko AS, Thomas GM, Martinod K, De Meyer SF, et al. Neutrophil extracellular traps promote deep vein thrombosis in mice. J Thromb Haemost. 2012;10(1):136-44.

53. Tanaka K, Koike Y, Shimura T, Okigami M, Ide S, Toiyama Y, et al. In vivo characterization of neutrophil extracellular traps in various organs of a murine sepsis model. PLoS One. 2014;9(11):e111888. 
medRxiv preprint doi: https://doi.org/10.1101/2020.04.09.20059626; this version posted April 14, 2020. The copyright holder for this preprint

(which was not certified by peer review) is the author/funder, who has granted medRxiv a license to display the preprint in perpetuity.

All rights reserved. No reuse allowed without permission.

54. Zhou F, Yu T, Du R, Fan G, Liu Y, Liu Z, et al. Clinical course and risk factors for mortality of adult inpatients with COVID-19 in Wuhan, China: a retrospective cohort study. Lancet. 2020;395(10229):1054-62.

55. Bunce PE, High SM, Nadjafi M, Stanley K, Liles WC, and Christian MD. Pandemic H1N1 influenza infection and vascular thrombosis. Clin Infect Dis. 2011;52(2):e14-7.

56. Pfeiler S, Massberg S, and Engelmann B. Biological basis and pathological relevance of microvascular thrombosis. Thromb Res. 2014;133 Suppl 1:S35-7.

57. Ma AC, and Kubes P. Platelets, neutrophils, and neutrophil extracellular traps (NETs) in sepsis. J Thromb Haemost. 2008;6(3):415-20.

58. Gould TJ, Vu TT, Swystun LL, Dwivedi DJ, Mai SH, Weitz JI, et al. Neutrophil extracellular traps promote thrombin generation through platelet-dependent and plateletindependent mechanisms. Arterioscler Thromb Vasc Biol. 2014;34(9):1977-84.

59. Kambas K, Chrysanthopoulou A, Vassilopoulos D, Apostolidou E, Skendros P, Girod A, et al. Tissue factor expression in neutrophil extracellular traps and neutrophil derived microparticles in antineutrophil cytoplasmic antibody associated vasculitis may promote thromboinflammation and the thrombophilic state associated with the disease. Ann Rheum Dis. 2014;73(10):1854-63.

60. Massberg S, Grahl L, von Bruehl ML, Manukyan D, Pfeiler S, Goosmann C, et al. Reciprocal coupling of coagulation and innate immunity via neutrophil serine proteases. Nat Med. 2010;16(8):887-96.

61. Liu X, Li Z, Liu S, Chen Z, Zhao Z, Huang Y-y, et al. Therapeutic effects of dipyridamole on COVID-19 patients with coagulation dysfunction. 2020:2020.02.27.20027557.

62. Thalin C, Hisada Y, Lundstrom S, Mackman N, and Wallen H. Neutrophil Extracellular Traps: Villains and Targets in Arterial, Venous, and Cancer-Associated Thrombosis. Arterioscler Thromb Vasc Biol. 2019;39(9):1724-38.

63. Barnado A, Crofford LJ, and Oates JC. At the Bedside: Neutrophil extracellular traps (NETs) as targets for biomarkers and therapies in autoimmune diseases. J Leukoc Biol. 2016;99(2):265-78.

64. Kessenbrock K, Krumbholz M, Schonermarck U, Back W, Gross WL, Werb Z, et al. Netting neutrophils in autoimmune small-vessel vasculitis. Nat Med. 2009;15(6):623-5. 
medRxiv preprint doi: https://doi.org/10.1101/2020.04.09.20059626; this version posted April 14, 2020. The copyright holder for this preprint (which was not certified by peer review) is the author/funder, who has granted medRxiv a license to display the preprint in perpetuity.

\section{ACKNOWLEDGEMENTS}

The work was supported by a COVID-19 Cardiovascular Impact Research Ignitor Grant from the Michigan Medicine Frankel Cardiovascular Center as well as by the A. Alfred Taubman Medical Research Institute. YZ was supported by career development grants from the Rheumatology Research Foundation and APS ACTION. JAM was partially supported by the VA Healthcare System. YK was supported by the NIH (K08HL131993, R01HL150392), Falk Medical Research Trust Catalyst Award, and the JOBST-American Venous Forum Award. JSK was supported by grants from the NIH (R01HL115138), Lupus Research Alliance, and Burroughs Wellcome Fund. YZ and JSK also thank all members of the "COVID-19 NETwork" for their helpful advice and encouragement.

\section{AUTHORSHIP}

$Y Z$, SY, HS, KG, JM, MZ, and CB conducted experiments and analyzed data. YZ, AW, BJB, ME, RJW, YK, and JSK conceived the study and analyzed data. All authors participated in writing the manuscript and gave approval before submission. 
Table 1: COVID-19 patient characteristics

\section{Demographics}

\begin{tabular}{|c|c|c|}
\hline & 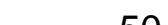 & \\
\hline Age (years)* & $61 \pm 15$ & $(29-91)$ \\
\hline Hospital day ${ }^{\star \star} \ddagger$ & $3.7 \pm 4.1$ & $(1-25)$ \\
\hline Female & 17 & $(34 \%)$ \\
\hline White/Caucasian & 19 & $(38 \%)$ \\
\hline Black/African-American & 29 & $(18 \%)$ \\
\hline \multicolumn{3}{|l|}{ Comorbidities } \\
\hline Diabetes & 16 & $(32 \%)$ \\
\hline Heart disease & 12 & $(24 \%)$ \\
\hline Renal disease & 16 & (32\%) \\
\hline Lung disease & 17 & $(34 \%)$ \\
\hline Autoimmune & 4 & $(8 \%)$ \\
\hline Cancer & 10 & $(20 \%)$ \\
\hline History of stroke & 3 & $(6 \%)$ \\
\hline Obesity & 23 & $(46 \%)$ \\
\hline Hypertension & 37 & $(74 \%)$ \\
\hline Immune deficiency & 3 & $(6 \%)$ \\
\hline History of smoking & 18 & $(36 \%)$ \\
\hline \multicolumn{3}{|l|}{ Medications $^{\ddagger}$} \\
\hline Antimalarials & 24 & $(48 \%)$ \\
\hline Anti-IL6 receptor & 2 & $(4 \%)$ \\
\hline ACE inhibitor & 1 & $(2 \%)$ \\
\hline Angiotensin receptor blocker & 0 & $(0 \%)$ \\
\hline Antibiotic & 22 & $(44 \%)$ \\
\hline Antiviral & 0 & $(0 \%)$ \\
\hline \multicolumn{3}{|l|}{ Respiratory status ${ }^{\ddagger}$} \\
\hline Mechanical ventilation & 16 & $(32 \%)$ \\
\hline High-flow oxygen & 2 & $(4 \%)$ \\
\hline Nasal-cannula oxygen & 17 & (34\%) \\
\hline Room air & 15 & $(30 \%)$ \\
\hline
\end{tabular}

* Mean \pm standard deviation

** Median $=2$

‡ At time of first sample available for testing 

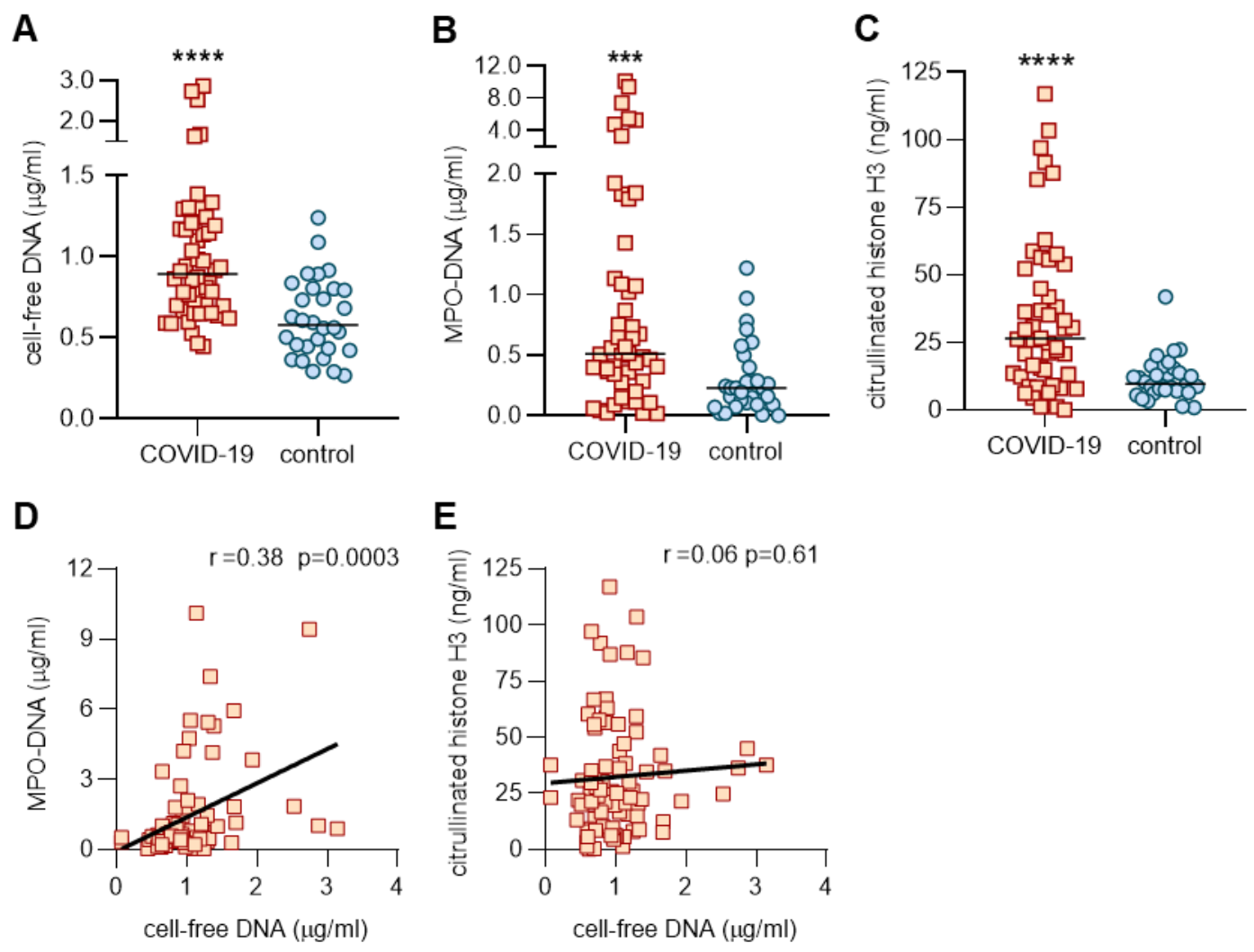

Figure 1: Detection of NETs in sera of COVID-19 patients. Sera from COVID-19 patients $(n=50)$ and healthy controls $(n=30)$ were assessed for cell-free DNA $(\mathbf{A})$, myeloperoxidase (MPO)-DNA complexes (B), or citrullinated histone H3 (C). COVID-19 samples were compared to controls by Mann-Whitney test; ${ }^{* * *} p<0.001,{ }^{* * * *} p<0.0001$. For the COVID-19 samples, correlation of cell-free DNA with MPO-DNA (D) and citrullinated histone H3 (E) were assessed. Pearson correlation coefficients were calculated and are shown in the panels. 
A

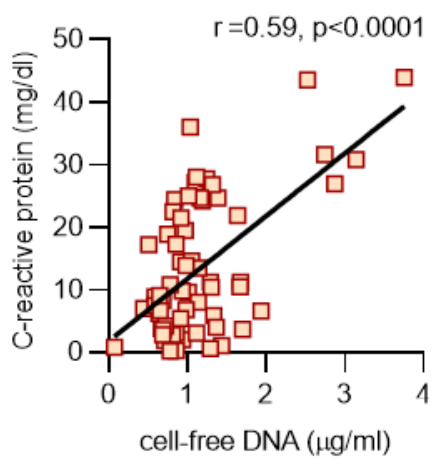

C

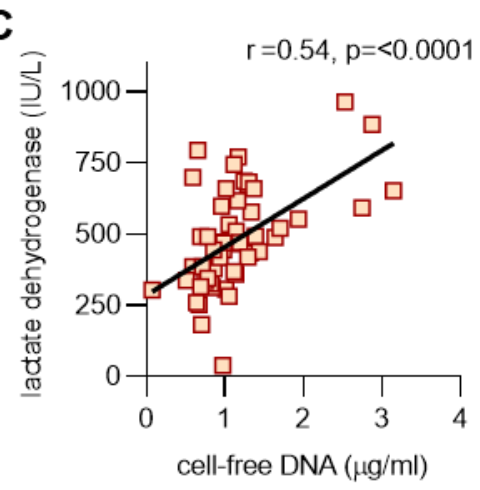

$\mathbf{E}$

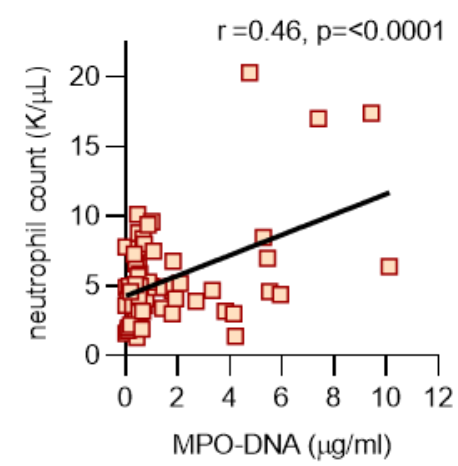

B

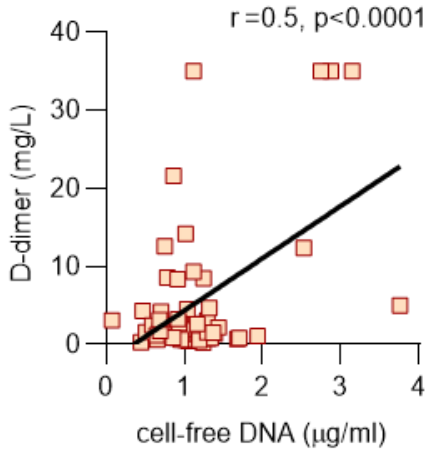

D

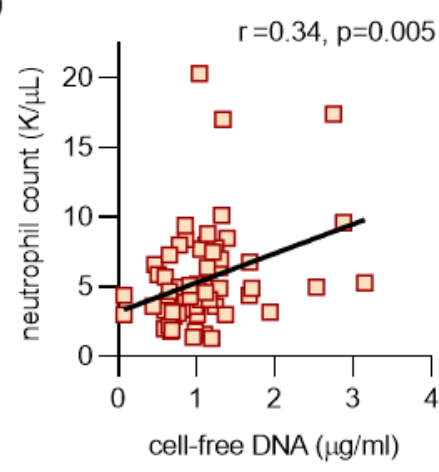

F

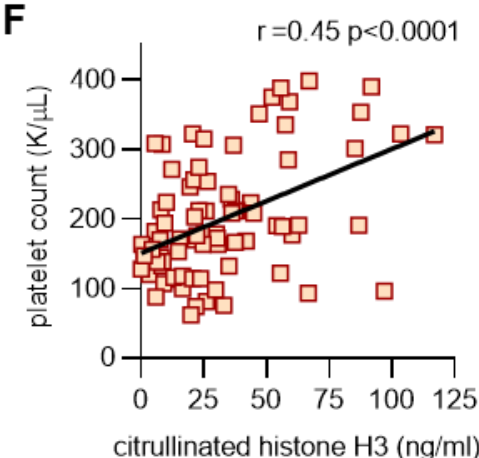

Figure 2: Association between NETs and clinical biomarkers in all available serum samples. Cell-free DNA was compared to clinical laboratory results (when available on the same day), and correlation coefficients were calculated for C-reactive protein (A), D-dimer (B), lactate dehydrogenase (C), and absolute neutrophil count (D). In panel E, MPO-DNA was compared to absolute neutrophils count and in $\mathbf{F}$, citrullinated histone $\mathrm{H} 3$ was compared to platelet count. The results of other relevant comparisons are discussed in the text. 
A

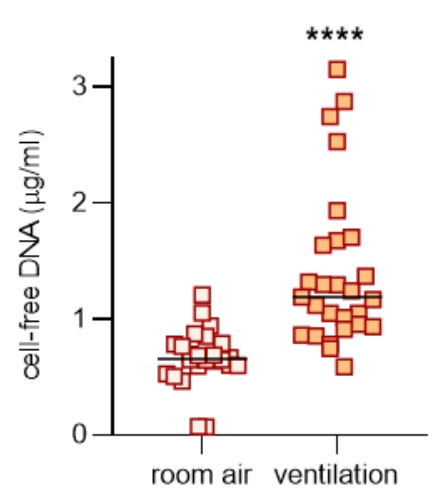

C

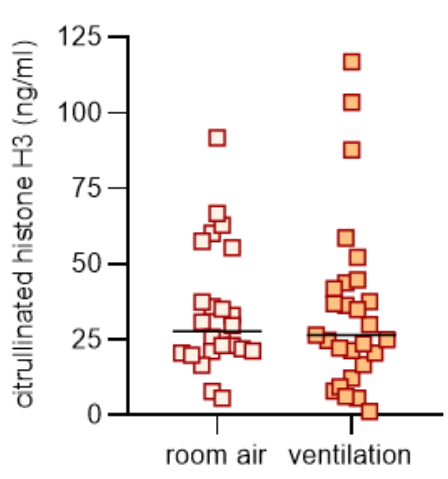

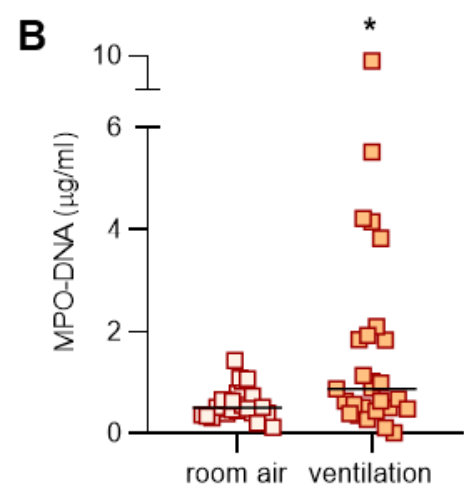

D

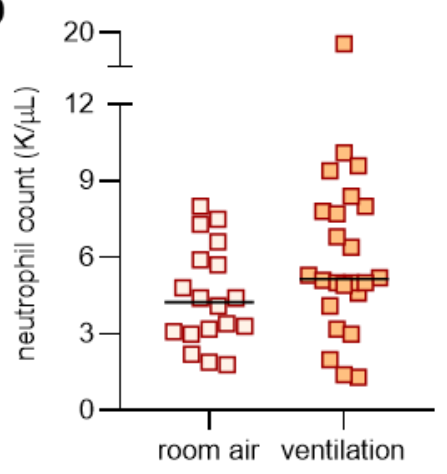

Figure 3: Levels of NETs associate with mechanical ventilation in all available serum samples. Serum samples were grouped by clinical status (room air versus mechanical ventilation), and analyzed for cell-free DNA (A), MPO-DNA (B), citrullinated histone H3 (C), and absolute neutrophil count (D). Groups were compared by Mann-Whitney test; ${ }^{* * *} p<0.0001$, ${ }^{*} p<0.05$. For panel $D$, the $p$ value was 0.08 . 

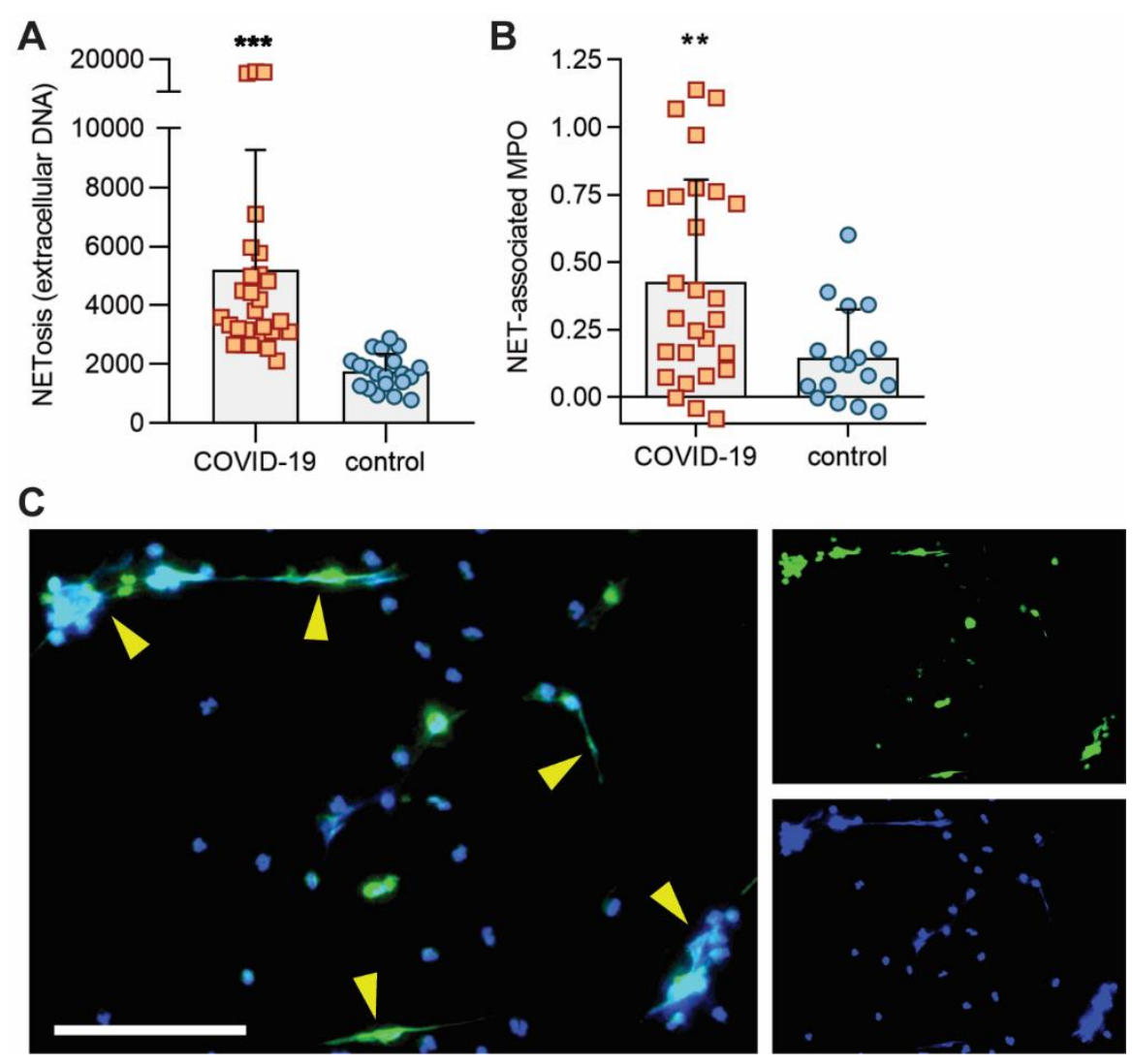

Figure 4: COVID-19 sera trigger control neutrophils to release NETs. COVID-19 samples (for which sufficient sera were available) were tested for their ability to trigger neutrophils isolated from healthy controls to undergo NETosis. A, NETosis was quantified using the cellimpermeant dye SYTOX Green as described in Methods. Fluorescence intensity (excitation/emission 504/523) is shown on the $y$-axis. Bars demonstrate mean and standard deviation while each data point represents a unique patient/control; ${ }^{* * *} \mathrm{p}<0.001$ by $t$ test. $\mathbf{B}$, In an independent set of experiments, NETosis was quantified as nuclease-liberated myeloperoxidase (MPO) activity. Absorbance at $450 \mathrm{~nm}$ is shown on the y-axis after subtracting background from untreated cells. Bars demonstrate mean and standard deviation while each data point represents a unique patient/control; ${ }^{* *} p<0.01$ by $t$ test. $\mathbf{C}$, Representative image of control neutrophils cultured with 10\% COVID-19 serum. Neutrophil elastase is stained green and DNA is stained blue. Scale bar=100 microns. The yellow arrows highlight some examples of NET strands. 
A

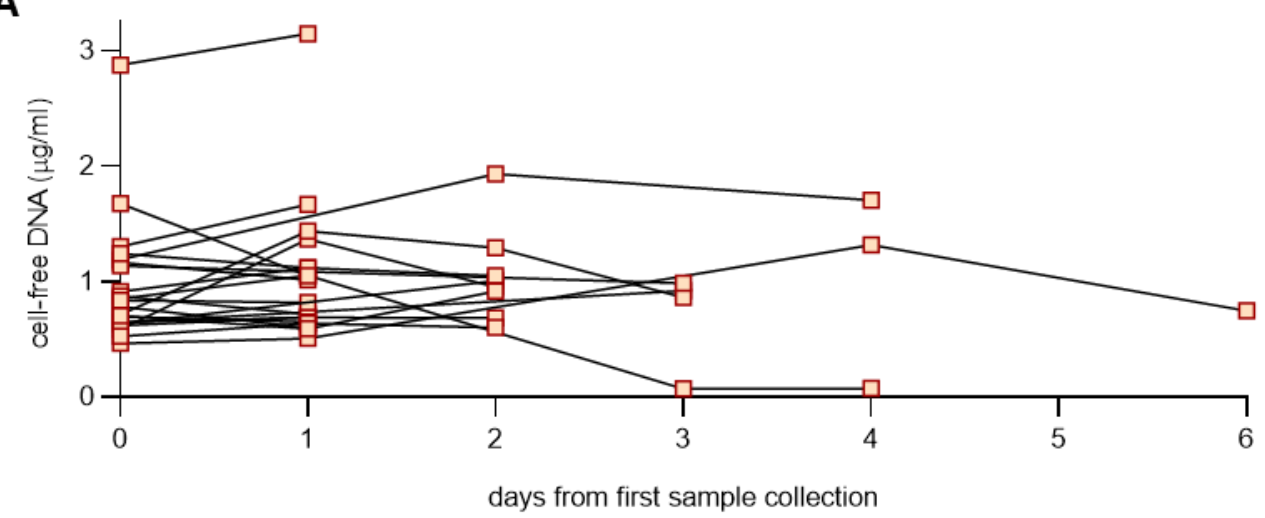

B

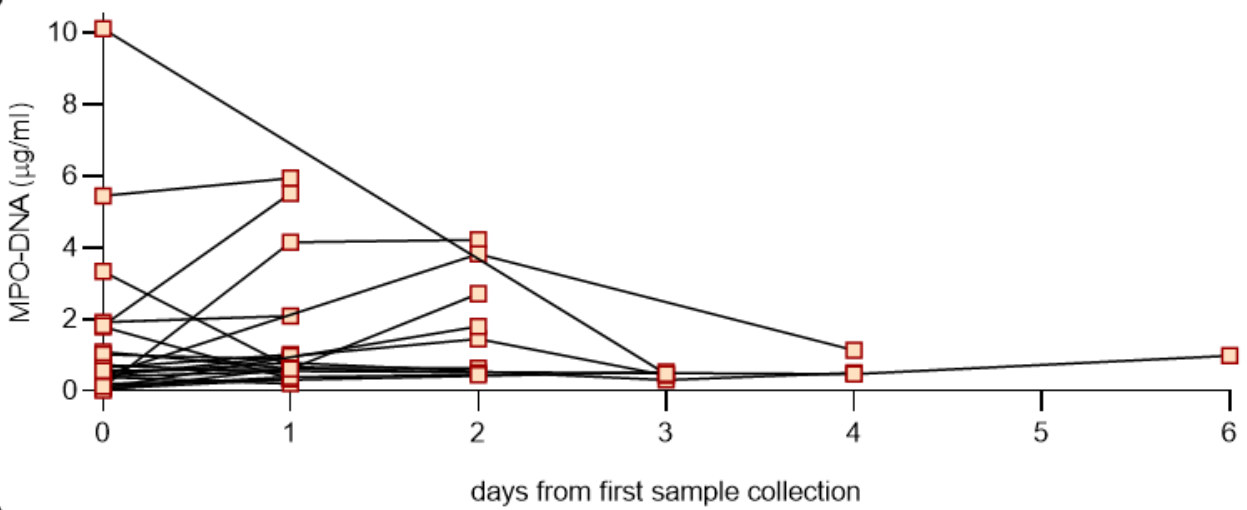

C

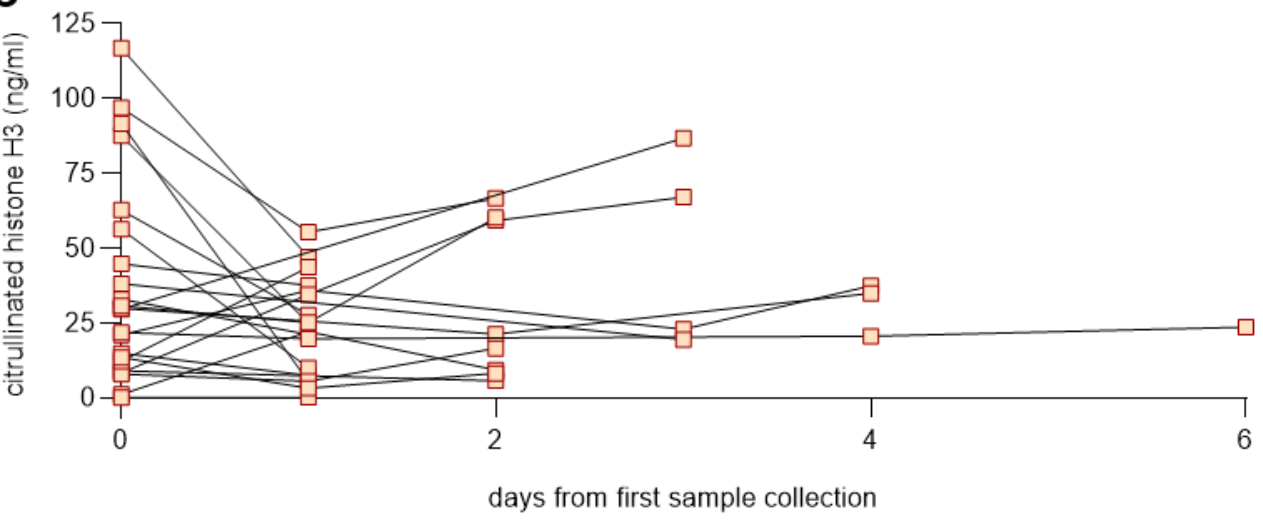

Supplementary Figure 1: Markers of NETs in longitudinal serum samples. For 22 patients, serum samples were available from multiple days. Data are plotted here for cell-free DNA (A), myeloperoxidase (MPO)-DNA (B), and citrullinated histone H3 (C). 